\author{
Bojana Gledić* \\ University of Belgrade \\ Faculty of Philology \\ Department of English Language, Literature and Culture
}

\title{
A WAR OF WORLDS IN A WORLD AT WAR: HISTORY AND MARGINALIZATION IN GRAHAM SWIFT'S NOVEL WISH YOU WERE HERE ${ }^{1}$
}

\author{
Original scientific paper \\ UDC 821.111.09-31 Swift G. \\ https://doi.org/10.18485/kkonline.2020.11.11.5
}

In his 2011 novel, titled Wish You Were Here, contemporary British author Graham Swift abandons his usual depiction of world wars as silent witnesses of times gone by and of a more structured, if questionably nobler, British past. Wish You Were Here explores contemporary warfare, both literal and metaphorical, at the same depicting a nation crumbling into itself. In this novel - history, instead of providing a coveted sense of structure, ceases to matter. In a way, it is non-existent. The main characters inhabit the world of the here and now, a world at war in more ways than one. The centre and the periphery shift, and the margin stands within Britain itself. While outsiders are nothing but a faraway threat, other Britons are the ones the main protagonists, being of a rural background, have to look out for. In this sense, Wish You Were Here presents a shift in the binary power relationship. The main protagonists fall outside of the hegemonic power structure, and the marginality that marks their existence is one within familiar territory. Consequently, otherness is characterized by feelings of disunity with the nation, and the aforementioned shift of the periphery is twofold, the main protagonists being both dislocated and displaced. The British men in the story almost resemble subalterns whose stories need to be heard.

Key words: war, history, marginalization, otherness, Graham Swift, Wish You Were Here

\section{Introduction - Graham Swift and the Imagery of War}

When one thinks of Graham Swift's novels, the first topic that comes to mind is that of the past and its complex role in the lives of ordinary people. After all, Graham Swift became famous for his depictions of history and his use of what has been dubbed as historiographic metafiction (Hutcheon, 1988; 1991) specifically in the case of his 1983 novel Waterland. However, aside from this novel, which is by far Swift's most

\footnotetext{
* Katedra za anglistiku, Filološki Fakultet, Studentski trg 3, 11000 Belgrade (Serbia); e-mail: bojanadgledic@gmail.com; bojana.gledic@fil.bg.ac.rs;

${ }_{1}^{1}$ This paper was presented at the Third International Conference on English Language, Literature, Teaching and Translation Studies - CELLTTS organized by the English Department of the University of Sarajevo (Bosnia and Herzegovina, Sarajevo, Faculty of Philosophy, September $28^{\text {th }}-29^{\text {th }}, 2018$ ) in the form of an oral presentation. The topic of the conference was inspired by the centennial of the end of WWI and it was titled "Living, Reading, Teaching and Translating in a World Dominated by the Culture of War and War of Cultures".
} 
famous piece of writing, his other work would not naturally fall into this category as in it he is more concerned with the role of history and its effects with regards to his fictional characters and their world(s) than the metafictional elements of novel-writing. Even Waterland itself could be described as a "fictional autobiography cum family history" (Robinson, 2011, p. xii) and any discussion on this novel could be redirected "from an overemphasis on epistemology" to "ethical issues" (Robinson, 2011, p. 83). Waterland remains Swift's only novel throughout which his authorial presence is evident, but history as the main theme has remained at the very heart of Swift's writing endeavours.

The predominant tropes in Swift's work are connected to the two world wars and they usually revolve around extraordinary people who performed extraordinary deeds. Such characters, reminiscent of those immortalized in Laurence Binyon's "For the Fallen" or Rupert Brooke's "The Soldier", add to a portrayal of the glory of Great Britain and its magnificent past which echoes better, more meaningful, times. In contrast, the present in Swift's novels is depicted as blurry and chaotic, and his characters are often caught inbetween a world they wished they lived in and their sombre surroundings. To them, the present is a dividing line that keeps them in limbo. In Swift's fiction, history serves as an elusive keeper of order and the past plays the role of a grand educator. From a contemporary perspective, however, one may start to question the justification of such views, as the British version of the past pertaining to the first half of the twentieth century has been under the spotlight, with the aim of bringing to light different versions of that past. One possible viewpoint is even perceiving Swift's work within the framework of postcolonial discourse, which has been attempted on several occasions (Gledić, 2016; 2018; 2019).

The most notable trait of the Swiftian past is the fact that, not unlike the pasts of most individuals, it consists of haunting memories. In Swift's work, one gets the impression that, as the great William Faulkner is known to have said, there is no such thing as the past: "There is no such thing as was - only is. If was existed, there would be no grief or sorrow." (Cowley, 1965, p. 141). Linda Hutcheon's opinion in connection with Swift's Waterland is complementary: even though the past did exist, it "exists for us - now - only as traces on and in the present" (Hutcheon, 1991, p. 73) and every individual makes their story personal. In the case of Swift's work, it is pivotal not to lose sight of the fact that the past he addresses in his novels is one of imperial legacy, as his novels usually depict characters who either lived during the large-scale world wars or are haunted by thoughts about a family member who was involved in one of 
them, but almost always live in their aftermath. Consequently, the memories presented in Swift's fiction are often memories of war and/or the impact a war has had (usually the Second World War) on a character's life. Perhaps it is not far-fetched to say that it would be expected for memories of war presented in fiction to exude scenes of chaos, carnage and human suffering. Yet, however paradoxical it may seem, in Swift's novels times of war seem much more appealing, and some of his characters could almost be described as having a constant need to go back to wartime or take part in it as their predecessors did. The most notable examples of such characters would perhaps be Irene from The Sweetshop Owner, who felt more at ease during wartime (Swift, 1997c, p. 60), Prentice in Shuttlecock who could not stop thinking about his father's wartime experiences (Swift, 1997b) or Harry's father in Out of This World; Robert Beech most obviously never wished to leave the war in his mind and was a victim of the proverbial "live by the sword, die by the sword", but his severed arm, nevertheless, constantly made people think of what a "great hero" he was (Swift, 1997a). Whatever one may think of the wars taking place in the real world, in Swift's fiction they mainly take on two roles - the first is somewhat paradoxical: war is a "safe", organized environment, while the second one is borderline epic - war is a stage for the performance of heroes. To sum up, all the abovementioned could be said to hold true for most of Swift's fiction, that is, up to the year 2011 and his novel Wish You Were Here. It may be said that this novel disrupted Swift's story pattern of various characters condoning the war and presented the war in a way that would be expected - as the bloody mayhem it is. However, this is not its most important distinction; by disrupting Swift's recurring images of war, Wish You Were Here also intensifies his depiction of a nation crumbling into itself, which will be presented in more detail in the paragraphs that follow.

\section{The Road Less Travelled in Wish You Were Here}

As it has been stated in the introductory paragraphs, Graham Swift's 2011 novel, Wish You Were Here, breaks with tradition when Swift's tropes are concerned. It does retain some of the topics Swift had previously touched upon, but they are presented in a completely new light. As the novel's epigraph from William Blake's "A Little Boy Lost" announces, the story of Wish You Were Here is very different. First and foremost, the main protagonists hail from a rural setting. While in Swift's previous novels a special connection with nature was reserved for women and other vulnerable groups (some examples of this would be Prentis's mother and wife in Shuttlecock, who 
share a secret language with flowers (Swift, 1997b, p. 35) or Prentis's view that only prisoners of sorts have a special connection to nature (Swift, 1997b, p. 154)), in Wish You Were Here nature is closely associated with raw masculinity. Jack's and Ellie's fathers, Michael Luxton and Jimmy Merrick, who own the Jebb and Westcott farms in Devon on which the main protagonists grow up, represent the ancient instinct for survival on one's own piece of land. Contrary to the examples of Swift's previous novels that have been mentioned, women cannot seem to find their place in the natural order of things; Jack's mother Vera dies, Ellie's mother Alice secretly escapes while Ellie is still a teenager, and Ellie does her very best (finally succeeding) to leave her childhood home. Both the natural and the supernatural seem to steer clear of the female characters in this novel. The centuries-old oak tree, a key element in the story, represents both nature and tradition, and the men in Jack's family have a special bond with it. When Jack's father commits suicide, the tree is complicit: "His father had simply wanted to press his head, his skull and his back hard against that oak tree and feel it pushing back. Spine against spine." (Swift, 2012, p. 246) and it provides him with a proper send-off to the netherworld. As opposed to this, almost sacred, connection, the tree frightens the female folk to a lesser or higher degree, as Ellie, even though she is decisive, only tentatively touches the hole in the tree (Swift, 2012, pp. 275-276) and the new lady of Jack's house, Mrs. Clare Robinson, is frightened by it on what was supposed to be a day of relaxation (Swift, 2012, pp. 320-324). Elements of the supernatural do not stop with the tree, and only a couple of examples will be mentioned. The spirits of the deceased roam the world of the living and Jack's dead brother, Tom, is a constant presence in Jack's life. Furthermore, the deaths of both Luxtons, the father and the son, take place in November, which is the month of blood according to Anglo-Saxon belief, because that was the month when the sacrificing of cattle took place (Bede, 1999, pp. 53-54). This is not a coincidence, since in Wish You Were Here Swift draws quite a few comparisons between people and livestock.

Although the county in which Jack and Ellie live is abundant in farms, the protagonists of Wish You Were Here seem isolated. They certainly do interact with one another, but these social encounters leave much to be desired, and it can be inferred that the family and inter-family relations in this novel are far from close-knit and functional. Tom and Jack's father seems clueless about the proper way to raise his sons, and both he and his neighbour perceive their children as little more than farmhands. Furthermore, even though one can guess that the two farmers shared a close friendship, as Jack at one point comments that they should have married each 
other (Swift, 2012, p. 45), and they died a very short time apart, the reader never actually sees how this friendship functions or evolves over time. Tom and Jack's mother, though a good mother and a loving wife, did not seem to feel a sense of belonging on the farm. Very few details about her life are given, but one can conclude from the episodes when she took her sons to the coast that she perhaps did want more for them than she could provide on the farm. The Luxton brothers are also a good example of this sense of alienation; while Tom is still on the farm, it is clear that Jack is supportive and full of brotherly love and understanding, but when Tom leaves it appears that this bond quickly breaks as the brothers quickly lose contact with each other. Ellie, the only character who remains on the farms until they are sold, constantly feels the need to be somewhere else. She envies her mother and feels an "odd, grudging admiration" (Swift, 2012, p. 33) towards her because she had the courage to run away. Ellie once tries to leave too, but unsuccessfully (Swift, 2012, pp. 37-40). At numerous points in her life she has to accept the fact that her father's farm and the Luxtons' farm are the world, and it seems only natural that she should marry Jack, although she will pay a very high price for this decision. The sense of psychological isolation is not something that is new in Graham Swift's fiction, but the physical isolation is. This is what also makes Wish You Were Here different.

Another important difference is that the war in Wish You Were Here is not temporally, but spatially remote, and the threat it presents lurks from afar. A general sense of fear is present throughout the novel, but the exact source of it remains unknown. The atmosphere of some of Swift's other novels could be described as somewhat grim (Paunović, 2006, p. 98)), but the insiduous darkness creeping from every corner is an element introduced in this piece of fiction. The blood and the slaughter, first of farm animals and then of soldiers, is something that is absent from Swift's other stories. The role of the warrior has also changed - the celebrated hero from Swift's previous work is substituted with an individual whose motives for partaking in the war and the purpose he is serving are questionable; according to Tom, if a soldier did not become a soldier, he would probably become a criminal, and to his mind that would have been his fate as well (Swift, 2012, p. 204). In contrast to Swift's other story lines, where the common people praised and looked up to famed war heroes, wishing they could be like them, in Wish You Were Here a representative of the military, Major Richards, who was the one to inform Jack about the details of his brother's death and repatriation process, has mixed feelings about contemporary warfare (Swift, 2012, p. 96). Even the most ordinary characters, such as the hearse 
drivers, Dave and Derek, the simple folk that one would assume feel nothing but love and support towards their home country, have their doubts. They question Tom's motive for going where he had gone and do not actually believe that he has died for his country (Swift, 2012, pp. 190-196). The local parishioner, Brookes, does not hide the fact that he condemns Tom's career choice of joining the military to fight in foreign countries (Tom had fought in Bosnia and then in Iraq), and it is quite clear that he is relieved that Tom's funeral will not include a flag, so no specially written speech is expected of him (Swift, 2012, p. 264). Consequently, he decides to speak only of Thomas as a local boy, not a soldier (Swift, 2012, p. 271). With such an episode in the novel, one gets the feeling that even God might not look upon such warfare with approval and sympathy. Last but not least, soldiers are equated with livestock in the terrible deaths they suffer - the scene in which Tom dies is reminiscent of the one in which the slaughtered livestock is burned following the culling order. In contrast to the glorious or at least happy endings of soldiers' careers in Swift's other novels, the outcome of choosing such a profession, as presented in Wish You Were Here, can lead to little more than dying a horrible death and arriving home in a casket draped with your country's flag (if your brother, like Tom's, does not decide to remove it).

\section{A War of Two Worlds in Wish You Were Here}

As it has been shown in the previous section, Wish You Were Here differs to a large extent from Swift's other fiction. The isolation he addressed previous to this novel was widely connected to a psychological feeling of isolation, while the isolation in Wish You Were Here is very real. As it has already been mentioned, all the characters in the novel experience a certain level of isolation throughout their lives, most notably Jack, whose example will be used to best illustrate the point at hand. Aside from going on holiday with his brother and mother on a couple of occasions (which were more than memorable for Jack, as the novel carries the title echoing the awkward text he wrote on a postcard for Ellie), the reader finds out, from Jack's story, that he practically never left the farm. Hard work and spending time with his family and the girl next door (who, naturally for such life circumstances, became his wife) were all that there was to life. Following the deaths of both their fathers, Jack and Ellie decide to sell their farms and leave, much to Jack's discomfort and unease. Ellie is the one insisting on leaving, and she does all in her power to do so. However, there is a hard price to pay, as Jack will refuse to have children because he has nothing left to leave them with. To his mind, the farm would have been the only place to raise children, because that is 
the only life he knows. Life on the Isle of Wight, his new life, is something he never gets accustomed to, and this is where one truly starts to realize how uncomfortable and alone he feels.

The name of the cottage Jack and Ellie come to inhabit has changed. What used to be called "The Sands", reminiscent of a beach, a holiday, and good times, is now called "The Lookout" bringing to mind images of watchmen on a tower, staring into the distance, waiting for the enemy to appear. In this sense, history seems to repeat itself: "It had once been where two now-forgotten souls had had the task, in theory, of guarding the whole country against invasion. But now everyone had to keep a lookout, didn't they?" (Swift, 2012, pp. 316-317). In Wish You Were Here, which takes place during "peacetime in the middle of England" (Swift, 2012, p. 149), not only is war an ominous threat, bringing more chaos into an already chaotic reality, but its scenes of carnage are not the only things scaring people. Imaginary threats, reminiscent of Constantine Cavafy's barbarians, clearly exist. A good example of this would be Jack's dismay at how guests at the lodgings he and Ellie provide are frightened of terrorists, because, in his opinion, they are on vacation, safe and far away from any threat (Swift, 2012, p. 61). Their life is quite different to his life - the real threat that he and the other farmers in his county faced with the outbreaks of the mad cow and the foot and mouth diseases meant little to anyone who did not live in the immediate vicinity of the farms. The damage and the loss were so great that Jack's father was not the only farmer to commit suicide, but this seems never to have been given much coverage in the news. On the other hand, an event like $9 / 11$, which is overseas and in a different country, will make Britons fear for their safety and future (Clare Robinson, whose husband has bought Jack's farm, is relieved to have bought a place in the country, in such times difficult for travel (Swift, 2012, p. 320)). These discrepancies clearly show the incompatibility of the world Jack Luxton and his kind live in, and the world the rest of Britons live in.

Jack strongly feels that there is this chasm between the two worlds, especially after leaving his farm. Contrary to the fact that he is living a more luxurious life than he ever dreamed of (for example, travelling to tropical islands for vacations), Jack appears to be living his life in constant fear. Once he has made the Isle of Wight his home (crossing the water was the first time he truly travelled), he is reluctant to leave it. When he needs to go and take care of Tom's remains and bury his brother, he is asked to bring his passport for identification purposes, but he feels that he will need it to disembark from the ferry. He feels that he is an alien entering a different country. 
He also constantly fears that he will be arrested (Swift, 2012, p. 136, p. 265); and even though this could perhaps be viewed as a sign of his guilty conscience, as it is never fully explained in the novel it could also be taken to mean that he feels that any territory outside his home is a hostile territory. At the air base, where he is due to receive his brother's remains, it becomes obvious that Jack does not know how to interact with people and that his social skills are limited. He barely makes it through the service, all the time feeling that somebody will come to take them all away to a terrible place of death (Swift, 2012, p. 166). And while it may be expected that an urban setting is somewhat uncomfortable for a farmer, what is especially interesting in Wish You Were Here is the reversal of nature's role as a protector of the vulnerable and its turning into a source of fear (on the Isle of Wight) or a backdrop to death and dying (in Iraq).

As the reading of Wish You Were Here progresses, one can mostly follow Jack's thoughts and his side of the story. The aspect that can provide the reader with the missing puzzle piece that clearly puts things into perspective is the acquisition of the farm by the Robinson family. Their attitude towards the farm is a clear indication of the way the rest of Great Britain may feel towards the old and forgotten ways of farm life. To the Robinsons, the farm is nothing but a place for spending free time, having fun and picnics with friends. During the purchase itself, Toby Robinson perceives Jack as someone from a different planet and they are literally barely able to communicate (Swift, 2012, p. 314). To the Robinsons, the farm is a good investment, and they do not care much about its history, its former use, or its role in British society, for that matter. According to this novel, British society has forgotten about its farmers, and the war of these two worlds is likely to have only one winner, and the farmers will not be it. Even the supernatural in the novel, which clearly takes the side of nature and the "old ways", does not help to strengthen the forces on that side of the battle. The ghosts of family and tradition, which have their own part to play in this story, can do nothing more but prolong the life of the remaining farmer folk, and it appears that the battle is futile. The way that Graham Swift presents this slow decline of an old way of life is truly unique in his corpus of fiction, which makes Wish You Were Here even more special and appealing to the reader.

\section{Wish You Were Here and a Nation at War}

It has been mentioned in the introductory section that history plays a different part in Wish You Were Here when compared to its part in Graham Swift's other fiction. 
The change of its role almost resembles the abandonment of the Whig method in British historiography. The Whigs' "style of understanding embraced the possibility that a war might defend justice and express the national character in some elevating way" (Bentley, 2006a, p. 82), and one might argue that certain protagonists of Swift's previous novels echo such sentiments. Among Whig historians, the British empire was viewed as a constitutional structure, but also provided a sense of a mission, "it embraced a destiny" (Bentley, 2006a, p. 70) but by 1960 it was noticeable "how passé had become not only the empire but the commonwealth that had become its heir." (Bentley, 2006a, p. 89). It is this undefined and undefinable sense of destiny that most of Swift's characters wish for and lack at the same time and, in his work prior to Wish You Were, they have a sense of what they are missing, because the stories about the glorious days of yore are ominpresent in their everyday lives. Depicting such circumstances is not purely a figment of fiction - the remnants of the "old days" of Empire are still very much present in the everyday life of contemporary British society. This was such an important (not to say, colossal) part of British history, that no attempt at deciphering its meaning can be undertaken without taking all its aspects into account. The modernists, who tried to cast this aside while dealing with the nature and limits of historical verity, succeeded only in turning epistemology into a practice for "seeking and confirming" truth (Bentley, 2006a, p. 209). This project failed, just like Swift's protagonists failed every time they tried to find palpable evidence of "truth" in the physical remnants of their personal and national histories. Without a personal involvement in the maze that the past and history create, the facts alone usually stand silent. As Michael Bentley put it, "The tyranny of the spatial matrix displaced from historical understanding the power of narrative and the place of temporal assumption in sustaining it." (2006b, p. 353). It is not an easy task to try and decipher what is behind us by using facts alone. And being excessively careful about rendering one's own "reading" of "the truth" can also lead to dead ends. While pursuing this path, the 1970s "banished the past into nothingness" (Bentley, 2006b, p. 354) but, according to this author, it is not a coincidence that the 1980 s and 1990 s were a time when the moment of memory emerged in historical writing and when narrative also re-emerged, "especially a narrative that focused on stories told as opposed to stories lived" (Bentley, 2006b, p. 354). This is to be expected because "When time is nothing but a formless screen, then historians need to write on it to lend it whatever meaning a present can divine for itself." (Bentley, 2006b, p. 354), and this is the only way for the past to become "present". For this very reason, dealing with the past requires a certain 
amount of imagination (Bentley, 2006b, p. 356). And despite the period of postmodernism rejecting any and all grand narratives, "most of all 'master narratives' of the kind that the Victorian whigs had offered" (Bentley, 2006a, p. 115), the element of storytelling may be returning to the historiography scene (Bentley, 2006a, p. 221) and rightly so. Graham Swift, who appears to be a fan of history and the intricate patterns it paints upon ordinary people's lives, allows the characters he creates to tackle history in different, sometimes opposite, ways. In his body of work, he explores the entire spectrum - from the grand narrative, through the neutral examination of hard facts, all the way to the (un)reliability of memory. In Shuttlecock, for example, the reader can experience a sense of history's greatness, in Ever After the search for hard facts, while Waterland deepens the search for meaning in the great depths of one's personal and national past, examining the role of memory and narrative in dealing with history. However, Wish You Were Here denounces all these approaches, as we shall see in the text that follows.

In opposition to the role of the grand educator and a constant reminder of a better, seemingly nobler, past, in Wish You Were Here the past is nothing but a silent bystander; it is there, but nobody takes any notice of it. Firstly, the long history of the Luxton farm appears to mean nothing - although it is constantly there, present in the life of the Luxton family, reminding them of a sense of family and tradition, it does little to alleviate their troubles and gives them no sense of either belonging or moving forward. Moreover, the old oak tree, a silent witness of times past, is complicit with Michael Luxton's suicide and with Jack and Ellie leaving. History means nothing as these events unfold. In addition to family history, which is nothing but a backdrop for violence and abandonment, Wish You Were Here also provides examples of collective history nobody pays any heed to. The annual event of celebrating Armistice Day in Marleston is described as more of an occasion for wearing one's best clothes and having a pint at the local pub than paying homage to those who have made the ultimate sacrifice for their country. Furthermore, this solemn day serves as an occasion for making personal plans of escape; Tom uses the money intended for his new suit to run away from home, while his father uses this day to decide to end his own life.

On the occasion of Armistice Day, as the village remembers the fallen, their names are just markings on a slab of stone (as they were, for example, in Graham Swift's Last Orders (Swift, 1996, pp. 127-129)), which can be expected, but nobody talks about them much. Again, as a contrast to Swift's usual story line, a woman, more precisely Jack's mother, is the one to fondly remember the soldiers in the family. She 
tells her son the story of their ancestors, George and Fred Luxton, but the little boy, instead of being impressed, finds fault in the story and deems it untrue. Thus, not even the little boy believes in fairy tales. However, even though he does not believe, and though he occasionally forgets about it, he cannot escape the memory - the medal from the story is one of the few things he will take from his old home to the new. And it is this specific item that he will take with him when he goes to pick up his brother's body. So, even though the story was probably not true, it seems that it was better than no story at all. Indeed, history as presented in Wish You Were Here resembles nothing more than a fairy tale or a forgotten memory that is always there, at the back of one's mind. So, in contrast with Graham Swift's trope of history as a great burden on the "little man", constantly reminding them of the inadequacy of their position in history's great legacy, in Wish You Were Here the end of history appears to have arrived, as one witnesses characters without history or a sense of belonging, wandering aimlessly in a cruel, merciless world distinguishable by fire and blood.

In addition to familial and local history, the history of the nation also takes on a different role in Wish You Were Here. In Swift's previous fiction, the reader had an unmistakable feeling of the characters' sense of having belonged to a great nation for decades and centuries. And even though many of his characters did not feel great themselves, their attitudes towards the celebrated history of the great British nation remained stable. In Wish You Were Here, the sense of nation is lost. First and foremost, the entire Luxton family and their neighbours, as it has been mentioned, do not feel a sense of connection either with their neighbours, the local community, the rest of Great Britain or the world for that matter. Having moved out of rural isolation, and having seen at least a small chunk of the rest of the world, Jack Luxton still does not feel that he belongs. And even though he has been placed at the border of a once great country, and taken on the role of a watchman who will be the first to see the enemy approaching, he does not perceive his role as such. Contrary to Swift's usual setting of the centre and the periphery being firmly in place, with protagonists walking along the thin line of the margin, but never straying from it, in Wish You Were Here the centre and the periphery have shifted, and both seem to be situated within Great Britain itself. Instead of being right in the centre of a great nation, Jack Luxton seems to be on the periphery. What is more, he feels different and he is afraid. With no viable explanation, he feels that his passport will serve to take him across the water to go back to his home village. On his way there, he does not pay much attention to the silent witnesses of a great national past - the former battle ships (aptly named Warrior 
and Victory) moored in the Portsmouth harbour. Once on the mainland, the proximity of cities makes him uneasy: "the word 'city' itself was foreign to him, as was the word 'citizen'" (Swift, 2012, p. 146). He observes people as one would observe foreign objects in a strange place, "the random sample of the nation" (Swift, 2012, p. 148). He most definitely does not consider himself to be part of the same group, whatever that group may be. Moreover, in addition to feeling as the Other, Jack Luxton obviously bears a grudge against his nation, which is clearly visible from his attitude towards the national flag. He firmly decides that a flag will not play a role in Tom's burial. One might explain this decision by concluding that Jack may have been angry at his country for sending his brother away to die far from home and all alone in a foreign land (he wonders whether at least his brother's coffin is made of "English oak" (Swift, 2012, p. 269)). In Wish You Were Here, Graham Swift also plays with the idea of what is considered sacred - at one point he equates the blanket of the beloved family dog with a national flag (Swift, 2012, p. 156), once again stressing the sense of alienation and otherness that people such as the Luxtons may feel in Great Britain's contemporary flow of history.

\section{The Burning Issues of Wish You Were Here}

In the previous sections, various reasons for which Wish You Were Here could not be considered Graham Swift's typical work of fiction have been presented. It might also be added that this particular novel is different because it deals with a somewhat unexpected topic for Swift, as well as more current affairs. At first glance, one might perceive this novel as a tragic story of the English village as an institution that is becoming extinct, or as criticism against the neocolonial policy of waging wars in faraway places such as Iraq, where Tom breathes his final breath. The location in the novel is triple - it takes place in the county of Devon, on the Isle of Wight and in Basra, Iraq - but although this is so, and even though the title of the novel echoes the lost world of sending postcards from one's travels - one gets the feeling that no one is really there, at these locations, and no one can truly understand the more silent than vocal protagonists telling this story. In this sense it is true that the novel contains both a sense of "place and 'no-place'" (Tollance, 2014). The overwhelming sense of alienation, dislocation and displacement of these characters makes one think of them as subalterns, who cannot or will not speak, and one's conception of them does not alleviate the absence of understanding. Wish You Were Here most certainly entails a shift in the binary power relationship, and instead of a feeling of supremacy, historically 
associated with the British nation, what characterizes the protagonists of this story is falling outside of the hegemonic power structure. The marginality that marks their existence is one within familiar territory, and although some borders they cross may be real (as is the case with Tom) most of those they cross are unreal (as is the case with Jack and Ellie). In contrast to being the Other in the (post)colonial sense, the otherness in Wish You Were Here is marked by feelings of disunity with the nation and struggling with an assigned identity. The aforementioned shift of the periphery is twofold, the main protagonists are both dislocated and displaced. Be it the case of Tom, who is taken out of his natural setting by the military, and placed into a far corner of the world to die, a "bumpkin" surrounded by "townies" (Swift, 2012, p. 207), or Jack and Ellie, whose dislocation turns into displacement and agony even though their moving from a place of hard work to a place of leisure was supposed to be for the better. And even though in all three cases the dislocation took place with the approval of the subject(s)/object(s), it took its toll nonetheless.

The proud sense of history and of belonging to a nation larger than life that existed in Swift's other novels served the main purpose of providing the characters with a sense of a "greater good" and the existence of something that is greater than themselves, that is something to aspire to, and consequently that is worth living and dying for. In Wish You Were Here, this role of "a greater good" is decentralized, resulting in the main characters' rejection of any assigned identity. As opposed to being a "deep, horizontal comradeship" (Anderson, 2006, p. 7) or having meanings "with which we can identify" (Hall, 2000, p. 613), the notion of nation in Wish You Were Here remains obscure. This problem seems to especially plague the men in the story, as they wander through their lives with no specific purpose. The role of the women, typically for Swift's work, is in the background and presented only in connection with the men. In this paper, the men in Wish You Were Here have been compared to subalterns; this is not too far-fetched as they are both socially and geographically outside the hegemonic relations that make up the imaginary homeland they are living in. The homeland that, at least judging by the plot in Wish You Were Here, is coming apart at the seams. The political aspect could also be said to be one of non-compliance, as there is an undercurrent of criticism of the political system in the story, but there is not enough material in the novel to further back up this claim. The subalterns in this story do not always speak, but it is their silence that speaks volumes to the reader. 
The ordinary people in Wish You Were Here are presented as victims of a system that is headed in a strange direction. Observations such as "one could say that Graham Swift, aesthetically mature, now uses terrorism to offer his reader a full and direct grasp of the powerful inner world of human feelings writing national and international history" and "the very terrorism Tom wants to fight against is presented as the global version of the anger- and awe-inspiring domestic and national circumstance" (Massoulier, 2014, p. 39) illustrate the points presented in this paper. The actual wars that the country is leading seem to be of no interest to anyone, apart from being just another topic for conversing with friends in one's free time or over drinks. The spirit of colonialism and of dominance seem to have taken over only those individuals who are superficial and apparently have no deeper connection with either their country or their roots (such as the Robinsons). The question of what one's country is exactly is addressed in this novel, as Ellie, a much more superficial character than Jack, seems to believe that by selling their farms, she and Jack will be selling "a little bit of England" (Swift, 2012, p. 285), while the Robinsons, who buy Jack's farm, seem to believe that that is exactly what they have bought, "their 'very own little piece of England'" (Swift, 2012, p. 327). And the questioning of belonging and patriotism does not end there. A very important topic Graham Swift addresses in this novel is the question of repatriation. On the one hand, the return of fallen soldiers' bodies to their homeland is supposed to be a solemn process, but it turns into a sort of show in which Jack has no idea how to play his part. It would be natural that he should know what to do, his family having lived on England's fertile soil for centuries, but he is numb, at a loss for words, and looking for his chance to leave the ceremony early. He does not understand what Tom had been fighting for since he left the farm. Moreover, he is not sure he understands what the Luxtons who died in the First World War had been fighting for, but this is at least a bit clearer to him (Swift, 2012, p. 178). This makes one wonder about all the fine structures that make up a nation, and whether stories about contemporary wars will make people in the future understand. It poses, once again, the question of the interconnectivity between nation and narration.

The role of television and the media plays a special part in making up the story of the nation in Wish You Were Here. As a sort of continuation of Harry Beech's story from Out of This World, Swift expands the notion that it is easier to view the world through a lens. In addition, if one takes a moment to remember the Coronation scene in this novel, where Sophie's husband Joe wonders why he and his family did not travel to see it, but are watching it on TV (Swift, 1997a, p. 151), this is also something that 
is further expanded in Wish You Were Here. And the similarities do not end there. In Out of This World one also witnessed the inaccessibility of travel for regular people, which was also the case with Jack and Ellie. While, on the one hand, Great Britain drew upon exploration and travel to build its power and greatness over the centuries, a large portion of its population was never in a position to contribute to this greatness or explore faraway horizons in such a way. And while it is obvious that Wish You Were Here is not about colonial expansion, the issue at hand is taking a step forward, crossing a border, and having a look at one's country from the outside. This is something that the characters in Wish You Were Here fail to do. Furthermore, not only are they not in a position to view their country objectively, they are not even in a position to understand it from the inside. And this is where the role of media comes in - to fabricate a story and fill in the missing pieces. The media makes the current affairs "real", and very few are not caught in its trap. Only characters lost in introspection, like Jack, see its negative impact and refuse to partake in its spectacle (Jack wishes to be "disconnected" (Swift, 2012, p. 224)). Finally, it may be added that this questioning of spinning the yarn of greatness is fortified in Wish You Were Here by a main protagonist who is atypical for Swift, and consequently History is not his story any more. And even though, once again, Swift's portrayal of female characters leaves a lot to be desired, Jack and the Luxton family cannot be considered as men in positions of power. On the contrary, as subalterns they belong to a vulnerable group, and it is of utmost importance for their story to be heard.

\section{Conclusion - All Is Fair in Love and War}

In Wish You Were Here, almost all the recurring tropes of Swift's fiction - the lessons the past teaches, the apparent harmony and order of history, the unruly disorder of a grim present; war as an almost safe, organized environment, with an inherent capacity to make ordinary people immortal; nature, a source of life, taking the side of the victim; and, finally, a sense of belonging in a world where the centre holds and the periphery is irrelevant or less important - are all abandoned and turned upside-down and inside-out. In Wish You Were Here, the past, far from being an educator, is a silent bystander watching people suffer, and history is nothing but a forgotten memory, at times resembling a magical, but tragically unreal, fairy tale. Contrary to being a stage for heroes to show the world and posterity how brave they are and how ready to fight for the country they love, the war in Wish You Were Here is a hellish, bloody mess and a scene of carnage. There are no heroes taking part in 
it, only ordinary people on their way to meeting destruction and death. Nature has ceased to be a protector of the weak and it serves as a backdrop to death and dying, indifferent and cold. The present described in this novel is even worse that the usual limbo that Graham Swift presents - it could be characterized as being almost (post)apocalyptic, which is further made worse by visitors arriving from the netherworld. As the centre and the periphery are shifted, it seems that all options remain open and all seems fair and unfair at the same time.

The final scene, where Jack and Ellie embrace, is reminiscent of a romantic love story, but the reader is aware of the fact that their version of paradise is far from perfect. Since it is a rainy night, the umbrella Jack is holding is covering the reader's view of them, but one does find out that the wind is trying to "wrest it [the umbrella] from Jack's battling grip, the rain beating a tattoo against it" (Swift, 2012, p. 353). As one can see, the squall will never leave their lives. However, they have both accepted that Tom's ghost is a part of their life, and it seems that all three together will battle on. No one can ever be certain what the future will bring, but in Jack and Ellie's case it might be argued that from their spot on the margins they will keep their mindful watch over the world, waiting to see whether it will all end in fire.

\section{References}

Anderson, B. (2006). Imagined Communities. Reflections on the Origin and Spread of Nationalism (Revised edition). London, New York: Verso.

Bede (1999). The Reckoning of Time (F. Wallis, Trans.). Liverpool: Liverpool University Press.

Bentley, M. (2006a). Modernizing England's Past. English Historiography in the Age of Modernism, 1870-1970. Cambridge: Cambridge University Press.

Bentley, M. (2006b). Past and "presence": Revisiting historical ontology. History and Theory 45 (October 2006), 349-361. Retrieved from https://onlinelibrary.wiley.com

Cowley, M. (Ed.). (1965). Writers at Work: The Paris Review Interviews. New York: The Viking Press.

Gledić, B. (2019). Faces of Empire in Graham Swift's Waterland. BELLS - Belgrade English Language and Literature Studies, volume XI, 227-246. 
Gledić, B. (2018). Hibridni identitet u romanima Grejama Svifta i Hanifa Kurejšija [Hybrid Identity in Novels by Graham Swift and Hanif Kureishi]. (Unpublished doctoral dissertation). Faculty of Philology, University of Belgrade, Belgrade, Serbia.

Gledić, B. (2016). Transformation of Britishness - Graham Swift as a postcolonial storyteller. BELLS - Belgrade English Language and Literature Studies, volume VIII, 319-330.

Hall, S. (2000). The question of cultural identity. In S. Hall et al. (Eds.), Modernity: An Introduction to Modern Societies, (pp. 595-634). Oxford: Blackwell Publishers Ltd.

Hutcheon, L. (1988). A Poetics of Postmodernism - History, Theory, Fiction. London: Routledge.

Hutcheon, L. (1991). The Politics of Postmodernism. New York \& London: Routledge. Massoulier, N. (2014). "Tremulations on the ether": The sublime and beauty in Graham Swift's humanist art. International Journal of English and Literature, Vol. 5(1), 34-44. DOI: 10.5897/IJEL2013.0523

Paunović, Z. (2006). Grejam Svift: U košmaru istorije. In: Z. Paunović, Istorija, fikcija, mit. Eseji o angloameričkoj književnosti, (pp. 94-98) Beograd: Geopoetika.

Robinson, A. (2011). Narrating the Past. Historiography, Memory and the Contemporary Novel. Basingstoke: Palgrave Macmillan.

Swift, G. (1996). Last Orders. London: Picador.

Swift, G. (1997a). Out of This World. London: Picador.

Swift, G. (1997b). Shuttlecock. London: Picador.

Swift, G. (1997c). The Sweet Shop Owner. London: Picador.

Swift, G. (2012). Wish You Were Here. London: Picador.

Tollance, P. (2014). Lieu et non-lieu dans Wish You Were Here de Graham Swift. Revue de la Société d'Études Anglaises Contemporaines, 47. Retrieved from https://journals.openedition.org/ebc/1772 